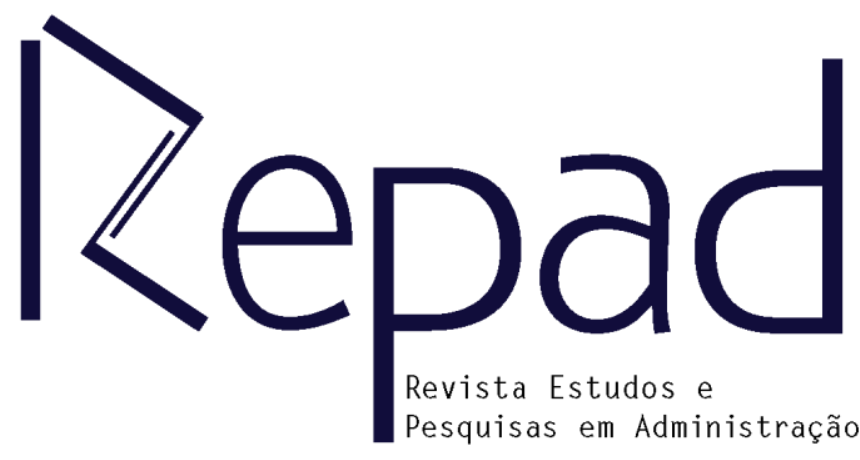

Revista Estudos

Pesquisas em Administração

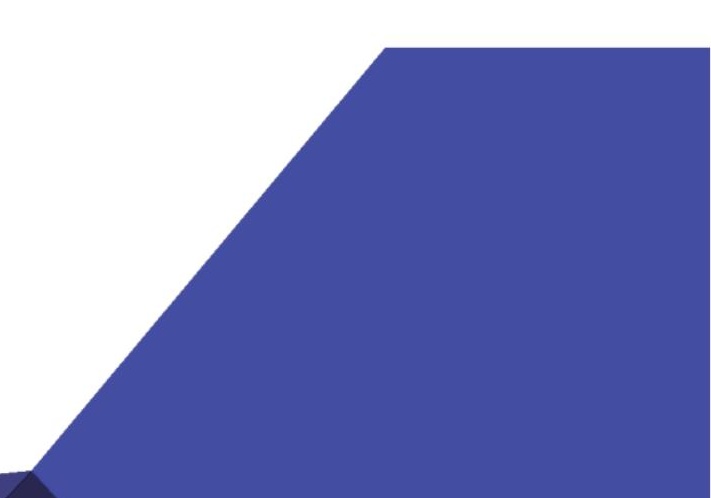




\section{Foco e Escopo}

A Revista Estudos e Pesquisas em Administração (Repad), publicada quadrimestralmente, é uma iniciativa do Curso de Administração da UFMT, Câmpus Rondonópolis, e tem a finalidade de publicar e divulgar ensaios teóricos e pesquisas teóricoempíricas já finalizados, de modo a disseminar o conhecimento científico entre acadêmicos e profissionais da área de administração e afins.

\section{Editor}

Prof. Dr. André Luís Janzkovski Cardoso

\section{Editora de Sessão}

Profa. Dra. Márcia Juliana d’Angelo

\section{Conselho Editorial}

André Luís Janzkovski Cardoso

Fernanda Pereira Silva

Heitor Lopes Ferreira

Ivânia Freire da Silva

Maurício Alves Rodrigues Pugas

Marcia Juliana d'Angelo

Neide Santos da Silva

Paulo Henrique Martins Desidério

Rodrigo Milano de Lucena

Roseli Aparecida dos Reis

\section{Editores de Texto}

Karine Lopes Ono

Ivânia Freire da Silva

Rodrigo Milano de Lucena

Roseli Aparecida dos Reis

Sandra Gimenes

\section{Editores de Layout}

Douglas Reginatto

Jennifer Nogueira Feitosa Silva

Serifo Salum

\section{Design gráfico}

Execução: Caroline Pedrozo

Supervisão de Design: Jessica Bastos

Secretaria de Comunicação e Multimeios

\section{Correspondências}

Av. dos Estudantes, 5005, Rondonópolis - MT

CEP 78735-901

Telefone: (66) 3410-4070

Site:

http://periodicoscientificos.ufmt.br/ojs/index.php/repad E-mail:

repadufmt@gmail.com

\section{Avaliadores e Pareceristas}

Prof. Dr. André Luís Janzkovski Cardoso, UFMT

Prof. Dr. Avilo Roberto Magalhães, UFMT

Prof. Dr. Carlos Eduardo Freitas, UFMT

Prof. Dr. Leandro Pessoa de Lucena, UFMT

Prof. Dr. Orlando Ramos Nascimento Jr., Uneal

Prof. Dr. Paulo Henrique Martins Desidério, UFMT

Prof. Dr. Rony Ahlfeldt, PUC-PR

Prof. Esp. Diogo Barbosa Leite, IFMT

Prof. Esp. José Alan Barbosa da Silva, Consultor

Prof. Dr. Heitor Lopes Ferreira, UFMT

Prof. Me. Maurício Alves Rodrigues Pugas, UFMT

Prof. Me. Rodrigo Milano de Lucena, UFMT

Profa. Dra. Cecilia Arlene Moraes, UFMT

Profa. Dra. Fernanda Pereira Silva, UFMT

Profa. Dra. Ivana Aparecida Ferrer Silva, UFMT

Profa. Dra. Márcia Juliana d'Angelo, Fucape

Profa. Dra. Marinês Taffarel, Unicentro

Profa. Dra. Priscila de Oliveira Xavier Scudder, UFMT

Profa. Dra. Suzimeri Vilas Boas Pescador, Unipar

Profa. Ma. Danieli Artuzi Pes Backes, UFMT

Profa. Ma. Idineia Bressan, Faculdade Católica-MT

Profa. Ma. Ivânia Freire da Silva, UFMT

Profa. Ma. Milady da Silva Oliveira, UFMT

Profa. Ma. Neide Santos da Silva, UFMT

Profa. Ma. Rosane Bueno Machado, Consultora

Profa. Ma. Roseli Aparecida dos Reis, UFMT

Profa. Ma. Sarah Caroline de Deus Pereira, Advogada

Profa. Ma. Valéria Sun Hwa Mazucato, Anhanguera-MS
REPAD, v. 3, n. 1, 2019 - Rondonópolis

UFMT/CUR, 2019

Quadrimestral

ISSN 2594-7559

1. Administração - Periódicos.

ed. 


\section{Editorial}

\section{Caros Leitores}

No primeiro artigo, Vera Sirlene Leonardo e Marco Antônio Carvalho Teixeira apresentaram um trabalho cujo objetivo foi analisar a implementação da atual política habitacional brasileira, a fim de demonstrar como as relações intergovernamentais são implementadas em uma política de cima para baixo, como o programa Minha Casa Minha Vida. A pesquisa é teórico-empírica, qualitativa, estudo de caso, com dados coletados por meio de entrevistas e documentos, cuja unidade de análise foi o município de Maringá-PR. Os resultados mostram que apenas $26 \%$ das unidades habitacionais foram produzidas no município para a população de baixa renda, enquanto o padrão de produção nacional para essa população é de cerca de $60 \%$. Os autores argumentam que as relações estabelecidas entre os entes federativos não foram suficientes para contemplar o contingente populacional que o governo central pretendia atender a fim de contribuir para a redução do déficit habitacional local. O segundo artigo, escrito por Edir Vilmar Henig, trouxe a discussão de que tanto os regimes ditatoriais quanto os períodos considerados democráticos tinham um nível acentuado de corrupção, mas no caso das ditaduras, o autoritarismo impedia investigações. Nesse sentido, o autor indica que a auditoria, que é um ramo da contabilidade, assume papel fundamental no combate a esse problema estrutural brasileiro. Os autores Aloisio Rodrigues da Silva, Almir Batista de Santana Júnior e Sofia Ines Niveiros tiveram como objetivo demonstrar os benefícios que a auditoria operacional pode oferecer à empresa em termos de seus setores gerenciais ou operacionais, melhorando processos, corrigindo erros devido à falta de aplicação de tais técnicas e manter o que é executado de forma eficaz e eficiente. Como resultado, foi possível aplicar o mapeamento de processos no setor operacional, obtendo resultados favoráveis de acordo com os próprios membros da empresa, executantes das atividades realizadas, que expressaram satisfação com a implementação de fluxogramas como forma de orientação para executar os processos da empresa e atingir seus objetivos. O quarto artigo, conduzido por Rosicley Nicolau de Siqueira, Diane Ellen Alves dos Santos, Cristiane Marafon, Daiane Alves Cardoso e Andrey Sartori, apresentou a aplicabilidade dos 5 sentidos em uma empresa de consultoria em Lean Manufacturing, realizada em dois setores: estoque de tecido e processos de acabamento/expedição na linha de uniformes profissionais. Os resultados deste estudo apresentaram a mudança de layout e ajustes para melhorar a produtividade do setor de transporte e a organização do estoque. Os autores Raimundo Moriman Goes Junior e André Luis Ribeiro Lacerda reuniram duas áreas centrais, Sociologia Econômica e Sociologia das Organizações, para investigar os processos de mudança social e modernização em estabelecimentos rurais produtores de leite, grãos e peixes, localizados no sudeste do estado de Mato Grosso, respondendo por que alguns estabelecimentos rurais se modernizam e outros não, usando a sociologia econômica de Granovetter e a teoria de redes. A observação estruturada foi adotada para verificar a existência de redes sociais no meio rural e se essas interações entre os agentes poderiam influenciar a modernização de seus estabelecimentos rurais. Hipólito Mendes e André Roese trazem um artigo sobre o Estudo de Caso como um método. Eles selecionaram "gestão ambiental" como a palavra-chave e os artigos classificados como estudo de caso, em administração de empresas, economia e engenharia. Vinte e um artigos foram analisados e os resultados foram apresentados no artigo. No sétimo artigo, escrito por Joseano Lira Santos, Alessandra Nunes Gomes, André Luís Scudeler, Felipe Guedes Moreira Vieira, Nícolas da Silva de Lima e Thaynára Orrana Pereira Pareci, os autores descreveram o Planejamento Estratégico como uma ferramenta para atingir metas e objetivos utilizados por Instituições públicas. O estudo baseou-se em uma análise bibliográfica e documental, método qualitativo e identificando as fases, características e vantagens do documento estratégico.

Esperamos que os resultados das pesquisas aqui apresentadas sirvam de base para novos artigos. Prof. Dr. André Luís Janzkovski Cardoso Editor-chefe 
RELAÇÕES INTERGOVERNAMENTAIS NAS POLÍTICAS PÚBLICAS: Uma análise da implementação do Programa Habitacional brasileiro Minha Casa Minha Vida (PMCMV)

Vera Sirlene Leonardo Marco Antônio Carvalho Teixeira

REFLEXÕES SOBRE AS CONTRIBUIÇÕES DA AUDITORIA CONTÁBIL NO COMBATE A CORRUPCÃO

Edir Vilmar Henig

AUDITORIA OPERACIONAL: Uma contribuição para melhoria de processo em uma empresa de pronta resposta de Rondonópolis-MT

Aloisio Rodrigues Da Silva Almir Batista de Santana Júnior Sofia Ines Niveiros

A APLICABILIDADE DOS 5 SENSOS COMO UMA FERRAMENTA ESTRATÉGICA DO LEAN MANUFACTURING - UM ESTUDO DE CASO NA INDÚSTRIA TEXTIL - CUIABÁ/MT

Rosicley Nicolao de Siqueira Dhaiany Ellen Alves dos Santos

Cristiane Marafon Daiane Alves Cardoso Andrey Sartori

REDES SOCIAIS E PROCESSO DE MODERNIZAÇÃO EM PEQUENOS E MÉDIOS ESTABELECIMENTOS RURAIS NA REGIÃO SUDESTE DE MATO GROSSO

Raimundo Moriman Goes Junior André Luis Ribeiro Lacerda

PANORAMA DOS ESTUDOS DE CASO DISPONÍVEIS NA PLATAFORMA DA SCIENTIFIC PERIODICALS ELETRONIC LIBRARY - SPELL

Hipólito Mendes André Roese

Joseano Lira Santos

ELABORAÇÃO DO PLANEJAMENTO ESTRATÉGICO NO INSTITUTO FEDERAL DE MATO GROSSO/CAMPUS AVANÇADO TANGARÁ DA SERRA 


\title{
RELAÇÕES INTERGOVERNAMENTAIS NAS POLÍTICAS PÚBLICAS: Uma análise da implementação do Programa Habitacional brasileiro Minha Casa Minha Vida (PMCMV)
}

\author{
Vera Sirlene Leonardo e Marco Antônio Carvalho Teixeira
}

\section{RESUMO}

O objetivo desse artigo é analisar a implementação da atual política habitacional brasileira de modo a demonstrar como são efetivadas as relações intergovernamentais numa política top down como é o Programa Minha Casa Minha Vida (PMCMV). A pesquisa é empírico-teórica, qualitativa, estudo de caso, com dados levantados por meio de entrevista e documentos, cuja unidade de análise é o município de Maringá-Pr. Os resultados mostram que foram produzidas no município apenas $26 \%$ de unidades habitacionais para a população de baixa renda, enquanto que o padrão nacional de produção para essa população gira em torno de $60 \%$. Concluiu-se que as relações que se estabeleceram entre os entes federativos não foram suficientes de modo a contemplar o contingente da população que o governo central se propunha a atender de forma a contribuir para a redução o déficit habitacional local.

Palavras-chave: Relações Intergovernamentais; Políticas Públicas; Implementação; Programa Minha Casa Minha Vida

\section{REFLEXÕES SOBRE AS CONTRIBUIÇÕES DA AUDITORIA CONTÁBIL NO COMBATE A CORRUPÇÃOO}

Edir Vilmar Henig

\section{RESUMO}

Tanto os regimes ditatoriais, quanto aos períodos tidos como democráticos tiveram um nível de corrupção acentuado, mas no caso das ditaduras, o autoritarismo impedia que investigações fossem realizadas, já no período democrático tivemos a queda de um presidente envolvido com corrupção. Mesmo com todas estas situações a corrupção não se esvaiu ao contrário, se aperfeiçoou e ganhou novos formatos, estes com mais dificuldade de serem detectados. Neste sentido, a auditoria, que é um ramo da contabilidade, assume papel fundamental no combate a este problema estrutural brasileiro, que apensar de ser possível sua identificação desde seus primórdios, ainda hoje acentua as mazelas sociais mais graves da sociedade e é encontrada em todos os níveis sociais, seja na esfera pública ou privada. Para este trabalho utilizamos análise documental como Leis e normatizações, e levantamento bibliográfico para fomentar a discussão em torno da temática. Tendo como objetivo básico, analisar a importância da auditoria na prevenção, identificação e combate da corrupção.

Palavras-chave: Corrupção. Auditoria. Administração Pública. 


\title{
AUDITORIA OPERACIONAL: Uma contribuição para melhoria de processo em uma empresa de pronta resposta de Rondonópolis-MT
}

\author{
Aloisio Rodrigues Da Silva, Almir Batista de Santana Júnior e Sofia Ines Niveiros
}

\section{RESUMO}

Este estudo objetiva demonstrar os benefícios que a auditoria operacional pode oferecer à empresa no que se refere a sua gestão ou seus setores operacionais, melhorando os processos, corrigindo os erros decorrentes da falta de aplicação de tais técnicas e mantendo aquilo que executa com eficácia e eficiência. A pesquisa é descritiva com abordagem qualitativa. A coleta de dados foi realizada através de um questionário numa empresa que faz parte do setor de prestação de serviços em pronta resposta, que abrange o território nacional, atuando a menos de dois anos. Os resultados apontam que a auditoria operacional exerce resultados positivos e relevantes no setor de operações de uma organização. Nesta empresa, cujos processos ainda não haviam sido definidos, pôde-se aplicar o mapeamento dos processos, no setor operacional, obtendo-se resultados favoráveis segundo os próprios integrantes da empresa, executantes das atividades nela exercidas, os quais expressaram a satisfação para com a implantação dos fluxogramas como forma de orientação para se executar os processos da empresa no atendimento aos seus objetivos.

Palavras-chave: Auditoria operacional. Processos. Micro e pequenas empresas.

\section{A APLICABILIDADE DOS 5 SENSOS COMO UMA FERRAMENTA ESTRATÉGICA DO LEAN MANUFACTURING - UM ESTUDO DE CASO NA INDÚSTRIA TEXTIL - CUIABÁ/MT}

Rosicley Nicolao de Siqueira, Dhaiany Ellen Alves dos Santos, Cristiane Marafon, Daiane Alves Cardoso e Andrey Sartori

\section{RESUMO}

O Sistema Lean Manufacturing é um processo de melhoria continua composto de ferramentas estratégicas, onde através de sua implantação e execução, tem como resultado o baixo custo evitando o retrabalho, facilitando no desenvolvimento do processo, tornando-se uma gestão inovadora e agregando valores ao produto final. Diante disso, este artigo tem como objetivo apresentar a aplicabilidade dos 5 sensos em uma consultoria em Lean Manufacturing, realizado em dois setores: estoque de tecidos e processo de acabamento/expedição na linha de uniformes profissionais. Os objetivos específicos que direcionaram a construção do trabalho consistem em identificar os principais gargalos do processo, envolver as pessoas, aplicar a ferramenta nos setores problemáticos. Os resultados deste estudo apresentam a mudança do layout e adequações para melhoria da produtividade do setor de expedição e a organização do estoque. Essa implementação aconteceu de forma sistêmica, onde primeiramente identificaram-se as falhas no processo e onde era necessário um aprimoramento da execução das tarefas, em seguida fez-se a aplicação da ferramenta 5S. Com a aplicação da Ferramenta $5 \mathrm{~S}$ nos setores envolvidos, implantaram-se as melhorias, possibilitando o levantamento quantitativo e qualitativo dos insumos e tecidos existentes proporcionado melhor otimização, reorganização e padronização das atividades.

Palavras-chave: Lean, Sensos, Processos 


\title{
REDES SOCIAIS E PROCESSO DE MODERNIZAÇÃO EM PEQUENOS E MÉDIOS ESTABELECIMENTOS RURAIS NA REGIÃO SUDESTE DE MATO GROSSO
}

\author{
Raimundo Moriman Goes Junior e André Luis Ribeiro Lacerda
}

\section{RESUMO}

O tema da pesquisa localiza-se na interseção entre a Sociologia Econômica e Sociologia das Organizações e tem como objetivo investigar o processo social de modernização, a partir da teoria das redes, em estabelecimentos rurais que produzem leite, grãos, peixe, com tamanho até 250 hectares, localizados na região sudeste do estado de Mato Grosso, basicamente nas cidades de Campo Verde e Juscimeira. Nos orientamos pela seguinte problemática de pesquisa: Por que alguns estabelecimentos rurais se modernizam e outros não? Partimos da sociologia econômica e a teoria dos laços sociais de Mark Granovetter para lançar a hipótese geral de que a estrutura social e as redes em que os responsáveis pelos estabelecimentos rurais estão inseridos explicam a modernização. Trata-se de estudo prévio desenvolvido na construção de dissertação de Mestrado do PPG em Sociologia da UFMT, portanto, esta pesquisa possui caráter exploratório, com intuito de familiarizarmos com nosso objeto de pesquisa. Como instrumento metodológico, utilizamos a observação estruturada, a fim de verificarmos o processo de modernização nos estabelecimentos rurais, bem como a existência de redes sociais.

Palavras-chave: Redes Sociais; Organizações; Estabelecimentos Rurais; Processo de Modernização.

\section{PANORAMA DOS ESTUDOS DE CASO DISPONÍVEIS NA PLATAFORMA DA SCIENTIFIC PERIODICALS ELETRONIC LIBRARY - SPELL}

Hipólito Mendes e André Roese

\section{RESUMO}

Apesar das críticas do passado por alguns cientistas sobre o questionamento de credibilidade do método de Estudo Caso, atualmente, dentre os métodos de pesquisa, o Estudo de Caso é um dos mais populares. Em alguns momentos as pesquisas que utilizaram esse método foram alvos de críticas no meio científico e em alguns casos confundido como um simples método ou estágio de pesquisa de caráter exploratório, ou como uma pesquisa etnográfica ou de observação participante. Portanto, há uma necessidade de imergir no campo de Estudo de Caso para melhor compreender como e quando se aplica. Uma das formas para esse entendimento é via análise das publicações científicas nos periódicos dependendo de período do interesse do pesquisador. Assim, este artigo objetivou analisar os estudos de caso publicados na base SPELL na área temática de gestão ambiental, nos anos 2015 a 2018. A análise se desdobrou em categorias como: nome das revistas publicadas, quantidades de artigos, principais palavras chave e classificação Qualis/CAPES por revista. O método utilizado para o levantamento dos dados desta pesquisa foi a partir da base científica Spell (Scientific Periodicals Electronic Library), utilizando-se "Gestão Ambiental" como palavra-chave. Quanto ao método de seleção de artigos, foram escolhidos os classificados como Estudo de Caso, publicados em resumos e periódicos entre 2015-2018, nas seguintes áreas de conhecimento: Administração, Economia, Engenharia, no idioma em Português. Quanto aos resultados apresentados na amostra dos vinte e um (21) artigos analisados, oito (8) artigos foram publicados na Revista de Gestão Ambiental e Sustentabilidade, três (3) artigos na Revista Desenvolvimento em Questão, dois (2) na Revista de Administração da Universidade Federal de Santa Maria - UFSM, dois (2) artigos na Revista Gestão e Sociedade, e um artigo em cada uma das outras cinco revistas encontradas.

Palavras-chave: Estudo de Caso. Gestão Ambiental. Spell 


\section{ELABORAÇÃO DO PLANEJAMENTO ESTRATÉGICO NO INSTITUTO FEDERAL DE MATO GROSSO/CAMPUS AVANÇADO TANGARÁ DA SERRA}

Joseano Lira Santos, Alessandra Nunes Gomes, André Luis Scudeler, Felipe Guedes Moreira Vieira, Nícolas da Silva de Lima e Thaynára Orrana Pereira Pareci

\section{RESUMO}

A denominação de Planejamento Estratégico constitui um conjunto de ações refletidas ao longo de um período de tempo para que se alcancem objetivos e metas. As ações utilizadas para que os objetivos sejam alcançados são definidas através da estratégia, enquanto o planejamento está relacionado à organização de cada uma destas decisões. Propõe-se uma abordagem delimitada relacionada ao Planejamento Estratégico, escrito num formato comparado ao Plano de Desenvolvimento Institucional cuja ferramenta é utilizada em Instituições Públicas, como órgãos escolares, para que eles se desenvolvam de maneira adequada; sendo o primeiro fruto do mercado empresarial, um instrumento de tomada de decisões adotado por quase todas as companhias do mercado, e com seu foco voltado para o aumento da produtividade e consequentes lucros. A referida pesquisa, empírica, é de base exploratória e descritiva, de análise bibliográfica e documental, com resultado qualitativo, no qual elaborou-se a pesquisa identificando as fases, as características e as vantagens do documento estratégico. Um dos pontos principais que relaciona os planejamentos em tela, é o estabelecimento da tríade missão, visão e valores da instituição onde serão implantados. Além disso, outro ponto em comum são suas vantagens, as quais visam a consolidação do trabalho, eficiência e eficácia das tarefas empregadas.

Palavras-chave: Planejamento Estratégico, Plano de Desenvolvimento Institucional, Instituto Federal. 


\section{Dear Readers}

In the first article, Vera Sirlene Leonardo and Marco Antônio Carvalho Teixeira presented a paper whose objective was to analyze the implementation of the current Brazilian housing policy in order to demonstrate how intergovernmental relations are implemented in a top-down policy, such as the Minha Casa Minha Life. The research is theoretical-empirical, qualitative, case study, with data collected through interviews and documents, whose unit of analysis was the municipality of Maringá-PR. The results show that only $26 \%$ of the housing units were produced in the municipality for the low income population, while the national production standard for this population is around $60 \%$. The authors argue that the relations established between the federative entities were not sufficient to contemplate the population contingent that the central government intended to attend in order to contribute to the reduction of the local housing deficit. The second article, written by Edir Vilmar Henig, brought the discussion that both dictatorial regimes and periods considered democratic had a marked level of corruption, but in the case of dictatorships, authoritarianism prevented investigations. In this sense, the author indicates that the audit, which is a branch of accounting, assumes a fundamental role in the fight against this Brazilian structural problem. The authors, Aloisio Rodrigues da Silva, Almir Batista de Santana Júnior and Sofia Ines Niveiros, aimed to demonstrate the benefits that the operational audit can offer to a company in terms of its managerial or operational sectors, improving processes, correcting errors and keep what runs efficiently and effectively. As a result, it was possible to apply the process mapping in the operational sector, obtaining favorable results according to the company members themselves, who performed the activities, who expressed satisfaction with the implementation of flowcharts as a guide to execute the processes of and achieve its goals. The fourth article, led by Rosicley Nicolau de Siqueira, Diane Ellen Alves dos Santos, Cristiane Marafon, Daiane Alves Cardoso and Andrey Sartori, presented the applicability of the 5 senses in a Lean Manufacturing consulting company, carried out in two sectors: fabric stock and finishing / dispatch processes in the line of professional uniforms. The results showed the change of layout and adjustments to improve the productivity of the transport sector and the organization of the inventory. The authors, Raimundo Moriman Goes Junior and André Luis Ribeiro Lacerda, gathered two central areas, Economic Sociology and Sociology of Organizations, to investigate the processes of social change and modernization in rural establishments producing milk, grains and fish, located in the southeast of the state of Mato Grosso, answering why some rural establishments are modernizing and others not, using Granovetter's economic sociology and network theory. Structured observation was adopted to verify the existence of social networks in rural areas and whether these interactions among agents could influence the modernization of their rural establishments. Hipólito Mendes and André Roese bring an article on the Case Study as a method. They selected "environmental management" as the keyword and articles classified as case study in business administration, economics and engineering areas. Twenty-one articles were analyzed and the results were presented in the article. In the seventh article, written by Joseano Lira Santos, Alessandra Nunes Gomes, André Luís Scudeler, Felipe Guedes Moreira Vieira, Nícolas da Silva de Lima and Thaynára Orrana Pereira Pareci, the authors described Strategic Planning as a tool to achieve goals and objectives used by Public institutions. The study was based on a bibliographic and documentary analysis, qualitative method and identifying the phases, characteristics and advantages of the strategic document.

We hope the search results presented here serve as a basis for new articles. Prof. Dr. André Luís Janzkovski Cardoso Editor-chief 
Editorial

INTERGOVERNMENTAL RELATIONS IN PUBLIC POLICIES: An analysis of the implementation of my house my life program (MCMV)

REFLECTIONS ABOUT CONTRIBUTIONS ACCOUNTANT AUDIT IN COMBAT OF THE CORRUPTION

\section{7}

Edir Vilmar Henig

OPERATIONAL AUDIT: A contribution to process improvement in a prompt response company of Rondonópolis-MT

THE APPLICABILITY OF THE 5 SENSES AS A LEAN MANUFACTURING STRATEGIC TOOL - A CASE STUDY IN THE TEXTILE INDUSTRY - CUIABÁ/MT Marco Antônio Carvalho Teixeira
Aloisio Rodrigues Da Silva Almir Batista de Santana Júnior Sofia Ines Niveiros

Rosicley Nicolao de Siqueira Dhaiany Ellen Alves dos Santos

Cristiane Marafon Daiane Alves Cardoso Andrey Sartori
SOCIAL NETWORKS AND MODERNIZATION PROCESSES IN SMALL AND MEDIUM SIZED RURAL ESTABLISHMENTS IN THE SOUTHEASTERN REGION OF MATO GROSSO

\section{4}

LANDSCAPE OF CASE STUDIES AVAILABLE ON THE SCIENTIFIC PERIODICALS ELETRONIC LIBRARY - SPELL

Hipólito Mendes André Roese

Joseano Lira Santos Alessandra Nunes Gomes André Luis Scudeler

ELABORATION OF STRATEGIC PLANNING AT THE FEDERAL INSTITUTE OF MATO GROSSO / CAMPUS ADVANCED TANGARÁ DA SERRA
Raimundo Moriman Goes Junior André Luis Ribeiro Lacerda 


\title{
INTERGOVERNMENTAL RELATIONS IN PUBLIC POLICIES: An analysis of the implementation of my house my life program (MCMV)
}

\section{Vera Sirlene Leonardo and Marco Antônio Carvalho Teixeira}

\begin{abstract}
The objective of this paper is to analyze the implementation of the current Brazilian housing policy in order to demonstrate how intergovernmental relations are implemented in a top down policy such as My House My Life Program. The research is empirical-theoretical, qualitative, case study, with data collected through interviews and documents, whose unit of analysis is the municipality of Maringá-Pr. The results show that only $26 \%$ of housing units were produced in the municipality for the low-income population, while the national production standard for this population is around $60 \%$. It was concluded that the relations established between the federative entities were not sufficient to contemplate the contingent of the population that the central government intended to attend in order to contribute to the reduction of the local housing deficit.
\end{abstract}

Keywords: Intergovernmental Relations; Public Policies; Implementation; My House My Life Program

\section{REFLECTIONS ABOUT CONTRIBUTIONS ACCOUNTANT AUDIT IN COMBAT OF THE CORRUPTION}

Edir Vilmar Henig

\begin{abstract}
Both the dictatorial regimes and the periods considered democratic had a marked level of corruption, but in the case of dictatorships, authoritarianism prevented investigations were carried out, even in the democratic period we had the fall of a president involved with corruption. Even with all these situations corruption did not disappear in the opposite direction, it has improved and gained new formats, these with more difficulty to be detected. In this sense, audit, which is a branch of accounting, assumes a fundamental role in combating this Brazilian structural problem, which, if it is possible to identify it from its beginnings, still today accentuates the most serious social problems of society and is found in all social levels, whether in the public or private sphere. For this work we use documentary analysis as Laws and norms, and bibliographical survey to foment the discussion around the thematic one. With the basic objective of analyzing the importance of auditing in the prevention, identification and combat of corruption.
\end{abstract}

Keywords: Corruption. Audit. Public administration. 


\title{
OPERATIONAL AUDIT: A contribution to process improvement in a prompt response company of Rondonópolis-MT
}

Aloisio Rodrigues Da Silva, Almir Batista de Santana Júnior and Sofia Ines Niveiros

\begin{abstract}
This study aims to demonstrate the benefits that the operational audit can offer the company in terms of its management or operational sectors, improving processes, correcting errors due to the lack of application of such techniques and maintaining what it executes effectively and efficiently. The research is descriptive with a qualitative approach. Data collection was performed through a questionnaire in a company which is part of the service sector in a prompt response, covers the national territory and has been operating for less than two years. The results indicate that the operational audit has positive and relevant results in the operations sector of an organization. In this company, whose processes had not yet been defined, it was possible to apply the process mapping in the operational sector, obtaining favorable results according to the company's own members, performers of the activities performed in it, who expressed satisfaction with the implementation of flowcharts as a form of guidance to execute the company's processes and meeting its objectives.
\end{abstract}

Keywords: Operational audit. Processes. Micro and small businesses.

\section{THE APPLICABILITY OF THE 5 SENSES AS A LEAN MANUFACTURING STRATEGIC TOOL - A CASE STUDY IN THE TEXTILE INDUSTRY - CUIABÁ/MT}

Rosicley Nicolao de Siqueira, Dhaiany Ellen Alves dos Santos, Cristiane Marafon, Daiane Alves Cardoso and Andrey Sartori

\begin{abstract}
The Lean Manufacturing System is a process of continuous improvement composed of strategic tools, whose implementation and execution result in low cost, avoiding rework, facilitating in the development of the process, becoming an innovative management and adding value to the final product. Therefore, this article aims to present the applicability of the 5 senses in a consulting company in Lean Manufacturing, carried out in two sectors: fabric stock and finishing / dispatch processes in the line of professional uniforms. The specific objectives that guided the study design are to identify the main bottlenecks of the process, to involve the people, to apply the tool in the problematic sectors. The results of this study present the layout change and adjustments to improve the productivity of the shipping sector and the organization of the stock This implementation occurred in a systemic way, in which the process failures were first identified and the execution of the tasks needed to be improved, then the $5 \mathrm{~S}$ tool was applied. With the application of the $5 \mathrm{~S}$ Tool in the sectors involved, the improvements were implemented, enabling a quantitative and qualitative survey of the existing supplies and fabrics, providing better optimization, reorganization and standardization of activities.
\end{abstract}

Keywords: Lean, Senses, Processes 


\title{
SOCIAL NETWORKS AND MODERNIZATION PROCESSES IN SMALL AND MEDIUM SIZED RURAL ESTABLISHMENTS IN THE SOUTHEASTERN REGION OF MATO GROSSO
}

\author{
Raimundo Moriman Goes Junior and André Luis Ribeiro Lacerda
}

\begin{abstract}
This paper theme is between two central areas, Economic Sociology and Sociology of Organizations and aims to investigate the social change and modernization processes in rural establishments which produce cow's milk, grains and fish and are up to 250 hectares, localized in the southeast of the state of Mato Grosso, basically in the cities of Campo Verde and Juscimeira. We are directed by the following problem: Why do some rural establishments modernize and others do not? In the light of this problem, we use Mark Granovetter's economic sociology and tie theory to investigate the general hypothesis that the modernization level of rural establishments may be explained by the social networks in which the ones responsible for them are involved. This research has the exploratory aim to get familiar with the study object. Structured observation was adopted in order to verify the existence of social networks in rural areas and whether these interactions between the agents may influence the modernization of their rural establishments.
\end{abstract}

Keywords: Social Networks; Rural Establishments; Modernization.

\section{LANDSCAPE OF CASE STUDIES AVAILABLE ON THE SCIENTIFIC PERIODICALS ELETRONIC LIBRARY - SPELL}

Hipólito Mendes and André Roese

\begin{abstract}
Despite some scientists' criticisms of the past on the question of the Case Study method credibility, currently, among the research methods, case study is one of the most popular. In some moments, studies using this method have been targets of criticism in the scientific world. In addition, the case study has been misunderstood as a simple method, an exploratory research stage, and even mistaken for the ethnographic research or participant observation. Therefore, there is a need to immerse in the field of case study to better understand how and when it applies. One way for it is via analysis of the scientific publications in journals depending on the period of interest of the researcher. Thus, this article aimed to analyze case studies published on the base SPELL in the thematic area of environmental management, from 2015 to 2018. The analysis involved categories such as: names of the journals published, number of articles, main keywords and Qualis/CAPES rate by journal. The method used for data collection was the scientific base Spell (Scientific Periodicals Electronic Library). We used "environmental management" as the keyword. As the method for article selection, we chose the ones classified as case study, published in the Portuguese language in the following areas of knowledge: Business Administration, economics and engineering. As for the approach, this work is of quantitative/qualitative nature. Twenty-one (21) articles were analyzed and the results showed that: eight (8) were published in the "Gestão Ambiental e Sustentabilidade" journal, three (3) in the "Desenvolvimento em Questão" journal, two (2) in the Administration Journal of the Federal University of Santa Maria - UFSM, two (2) in the "Gestão e Sociedade" journal and one article for each of the five journals found.
\end{abstract}

Keyword: Case Study. Environmental management. Spell 


\title{
ELABORATION OF STRATEGIC PLANNING AT THE FEDERAL INSTITUTE OF MATO GROSSO / CAMPUS ADVANCED TANGARÁ DA SERRA
}

Joseano Lira Santos, Alessandra Nunes Gomes, André Luis Scudeler, Felipe Guedes Moreira Vieira, Nícolas da Silva de Lima and Thaynára Orrana Pereira Pareci

\begin{abstract}
The name of Strategic Planning is a set of actions reflected over a period of time in order to achieve goals and targets. The actions used to achieve the objectives are defined through strategy, while planning is related to the organization of each of these decisions. It proposes a delimited approach related to Strategic Planning, written in a format compared to the Institutional Development Plan. This being a tool used in Public Institutions, such as school organs, so that they develop properly; being the first fruit of the business market, a decision-making instrument adopted by almost all companies in the market, with its focus on increasing productivity and consequent profits. This study is based on an exploratory and described bibliographic and documentary analysis, with a qualitative result, in which the research was elaborated identifying the phases, characteristics and advantages of the strategic document. One of the main points that relates the screen plans is the establishment of the triad's mission, vision and values of the institution where they will be implemented. In addition, another point in common is its advantages, which aim at consolidating the work, efficiency and effectiveness of the tasks employed.
\end{abstract}

Keywords: Strategic Planning, Institutional Development Plan, Federal Institute 